CLINICAL STUDY

\title{
Pathohistological classification of pituitary tumors: 10 years of experience with the German Pituitary Tumor Registry
}

\author{
Wolfgang Saeger, Dieter K Lüdecke ${ }^{1}$, Michael Buchfelder ${ }^{2}$, Rudolf Fahlbusch ${ }^{2,3}$, Hans-Jürgen Quabbe ${ }^{4}$ \\ and Stephan Petersenn ${ }^{5}$ \\ Institute of Pathology, Marienkrakenhaus, Alfredstraße 9 D-22087 Hamburg, ${ }^{1}$ Department of Neurosurgery, University of Hamburg, Germany, \\ ${ }^{2}$ Department of Neurosurgery, University of Erlangen-Nürnberg, Erlangen, Germany, ${ }^{3}$ Center of Endocrine Neurosurgery, International Neuroscience \\ Institute, Hannover, Germany, ${ }^{4}$ Department of Endocrinology, Klinikum Benjamin-Fraenklin, Free University of Berlin, Berlin, Germany and ${ }^{5}$ Division of \\ Endocrinology, Medical Center, University of Duisburg-Essen, Essen, Germany
}

(Correspondence should be addressed to W Saeger; Email: WolfgangSaeger.HH@t-online.de)

\begin{abstract}
In 1996, the German Registry of Pituitary Tumors was founded by the Pituitary Section of the German Society of Endocrinology as a reference center for collection and consultant pathohistological studies of pituitary tumors. The experiences of the first 10 years of this registry based on 4122 cases will herein be reported. The data supplement former collections of the years 1970-1995 with 3480 surgically removed tumors or lesions of the pituitary region. The cases were studied using histology, immunostainings and in some cases also molecular pathology or electron microscopy. The adenomas were classified according to the current World Health Organization classification in the version of 2004. From 1996 on 3489 adenomas (84.6\%), 5 pituitary carcinomas (0.12\%), 133 craniopharyngiomas (3.2\%), 39 meningiomas $(0.94 \%), 25$ metastases $(0.6 \%), 22$ chordomas $(0.5 \%), 115$ cystic non-neoplastic lesions $(2.8 \%)$, and 46 inflammatory lesions $(1.1 \%, 248$ other lesions or normal tissue $(6.0 \%))$ were collected by us. The adenomas $(100 \%)$ were classified into densely granulated GH cell adenomas $(9.2 \%)$, sparsely granulated GH cell adenomas $(6.3 \%)$, sparsely granulated prolactin (PRL) cell adenomas $(8.9 \%)$, densely granulated PRL cell adenomas $(0.3 \%)$, mixed GH/PRL cell adenomas (5.2\%), mammosomatotropic adenomas (1.1\%), acidophilic stem cell adenomas $(0.2 \%)$, densely granulated ACTH cell adenomas (7.2\%), sparsely granulated ACTH cell adenomas $(7.9 \%)$, Crooke cell adenomas $(0.03 \%)$, TSH cell adenomas (1.5\%), FSH/LH cell adenomas $(24.8 \%)$, null cell adenomas (19.3\%), null cell adenoma, oncocytic variant (5.8\%), and plurihormonal adenomas (1.3\%). Following the WHO classification of 2004, the new entity 'atypical adenoma' was found in 12 cases in 2005. Various prognostic parameters and clinical implications are discussed.
\end{abstract}

European Journal of Endocrinology 156 203-216

\section{Introduction}

Clinically relevant pituitary tumors presenting with disturbances of hormonal secretion or mass effect are rare, with an estimated prevalence of 200/1 000000 and an incidence of 2/100 000 per year (1-3). However, pituitary tumors are increasingly detected incidentally in $3.7-20 \%$ of computed tomography (CT) and approximately $10 \%$ of magnetic resonance imaging (MRI) scans of the central nervous system (CNS) performed for unrelated reasons $(4,5)$. Furthermore, about $10 \%$ of all pituitaries in unselected series of postmortem examinations show small adenomas $(6,7)$. Most of these are presumably hormonally inactive adenomas with no clinical significance during lifetime of the patient. The optimal management of such incidentalomas is still unclear (8). The management of clinically relevant pituitary tumors has changed quite dramatically in recent years. New medical treatment and radiation options became available in addition to advanced neurosurgical techniques. Optimal advice to the patient about these possibilities necessitates a precise characterization of the tumor. Whereas pituitary tumors are clinically differentiated mainly on the basis of their size and hormonal secretion, pathology offers further classification using sophisticated techniques. The present studies on the comparison of different treatment options mostly rely on the clinical diagnosis from endocrine characteristics. However, future studies may need to address differences in tumor behavior based on the pathogenesis and the pathohistological evaluation of the tumor. Furthermore with advancing diagnostic endocrine tests and radiological evaluation techniques, these procedures may need to be evaluated in comparison with the subclassification offered by pathology. Nowadays, pathohistological classification of pituitary 
adenomas according to the WHO criteria is very sophisticated and requires a high methodological standard. A registry for pituitary tumors that classifies the tumors by such methods may allow a better standardization of the diagnosis and therapy. Furthermore comparison with other countries could provide new insight in specific ethnic and behavioral differences in the pathogenesis of pituitary tumors. Lastly, such a registry may act as a reference center to enable improvements in the pathohistological diagnosis of pituitary tumors in local centers. With these aims in mind, the Pituitary Section of the German Society of Endocrinology founded the German Pituitary Tumor Registry offering co-operation with endocrinologists, neurosurgeons, and pathologists. Between 1996 and 2005, 4122 surgical cases were registered here and are presented in this review. In addition to the analysis summarizing 10 years of experience with the registry, this review may aid the establishment of registries in countries in which such an institution has not yet been founded.

\section{Structure of the German Pituitary Tumor Registry}

Tissue specimens obtained during surgery of pituitary or other sellar region lesions were mainly collected from ten centers (Table 1 , defined by $>1 \%$ of all contributors), with additional individual problematic tumors submitted to the registry for counsel by many other centers. Samples were sent to the Institute of Pathology of the Marienkrankenhaus Hamburg, Germany, as formalin-fixed or glutaraldehyde-fixed samples or as paraffin-embedded specimens. Clinical information could be entered into a standardized questionnaire provided to all centers. Detailed analyses of the registry are presented at the yearly meeting of the German Pituitary Group. The German Pituitary Tumor Registry was partly funded by unrestricted grants from Novartis Pharma GmbH, Ipsen Pharma GmbH, Ettlingen, Germany, Pfizer Pharma GmbH, Karlsruhe, Germany, and NovoNordisk Pharma GmbH, Mainz, Germany.

Table 1 Numbers of tumors sent from different centers to the German Registry of Pituitary Tumors, 1996-2005 ( $N=4122)$.

\begin{tabular}{lcc}
\hline Center & Number $(N)$ & Percentage (\%) \\
\hline Hamburg & 1285 & 31.2 \\
Erlangen-Nuremberg & 935 & 22.7 \\
Göttingen & 658 & 16.0 \\
Bremen & 239 & 5.8 \\
Munich & 233 & 5.6 \\
Karlsruhe & 102 & 2.5 \\
Erfurt & 94 & 2.3 \\
Gießen & 75 & 1.8 \\
Münster & 48 & 1.2 \\
Wuppertal & 43 & 1.0 \\
All others & 410 & 9.9 \\
\hline
\end{tabular}

\section{Methods used for histopathological characterization}

If enough material was available and the fixation was suitable, specimens were postfixed in osmium tetroxide and embedded in Epon 812 for semithin toluidine blue-stained sections or electron microscopy. Evaluation by electron microscopy was necessary in 22 problematic cases. Paraffin sections were stained with hematoxylin-eosin and periodic acid schiff (PAS), and used for immunostaining with monoclonal antibodies (MAB) against the specific pituitary hormones, such as growth hormone (GH; Sigma Immunochem, 1:200, Marseille, France, avidin-biotin-peroxidase complex $(\mathrm{ABC})$ ), PRL (1:400, Immunochem, $\mathrm{ABC})$, thyroidstimulating hormone (TSH; Immunotech, 1:5000, $\mathrm{ABC})$, luteinizing hormone ( $\mathrm{LH} ;$ Immunotech, $1: 40000, \mathrm{ABC})$, and follicle-stimulating hormone (FSH; Immunotech, 1:40 000, ABC). For adrenocorticotrophic hormone (ACTH), a polyclonal antibody was used (Zymed, San Francisco, CA, USA, 1:200, ABC). The glycoprotein $\alpha$-subunit was detected with a specific MAB (Immunotech, 1:1500, ABC). Cell proliferation was assessed by staining with an MAB for Ki-67 (MiB-1; Zymed, 1:150, ABC) and counting of mitoses per highpower visual fields. S100 expression as a marker for folliculostellate cells was analyzed by staining with $\mathrm{MAB}$ (Dako, Glostrup, Denmark, 1:1500, ABC). Expression of the $\mathrm{p} 53$ protein was evaluated in a subgroup of tumors suspected of being atypical adenomas using an MAB (Novocastra, Newcastle upon Tyne, UK, 1:80, ABC). For positive controls of pituitary hormones, normal postmortem pituitaries were used.

\section{Principles of classification}

According to the 2004 WHO classification (9), pituitary tumors are defined as neoplasms located in the sella turcica. Adenomas $(84.6 \%$ of all cases in our registry; Table 2) deriving from adenohypophysial parenchymal cells are classified as typical adenomas or atypical adenomas. In very rare cases, they represent pituitary carcinomas $(0.12 \%$ of all cases in our registry; Table 2$)$. In contrast to typical adenomas, atypical adenomas are defined by (a) their invasiveness, (b) a Ki-67 (MiB-1) proliferation index of $3 \%$ or more, and (c) an extensive nuclear staining for $\mathrm{p} 53$ protein. Pituitary carcinomas are characterized by the presence of metastases. Brain invasion as the only criterion of malignancy is generally not accepted. Pituitary adenomas are also classified according to the size. Microadenomas are $<10 \mathrm{~mm}$ in size, whereas macroadenomas have an estimated diameter of at least $10 \mathrm{~mm}$. Most importantly, pituitary adenomas are classified by their similarity to normal parenchymal cells and the expression of specific pituitary hormones. 
Table 2 Tumors of the pituitary and sellar regions in the German Registry of Pituitary Tumors, 1996-2005 ( $N=4122)$.

\begin{tabular}{|c|c|c|}
\hline Tumor type & $\begin{array}{l}\text { Number } \\
(N)\end{array}$ & $\begin{array}{l}\text { Percentage } \\
\quad(\%)\end{array}$ \\
\hline Pituitary adenoma & 3489 & 84.6 \\
\hline Pituitary carcinoma & 5 & 0.12 \\
\hline Craniopharyngioma, adamantinous & 121 & 2.9 \\
\hline Craniopharyngioma, papillary & 12 & 0.3 \\
\hline Meningioma & 39 & 0.94 \\
\hline Chordoma & 22 & 0.5 \\
\hline Metastasis & 25 & 0.6 \\
\hline Squamous carcinoma & 2 & 0.05 \\
\hline Gangliocytoma (with adenoma) & $14(13)$ & $0.34(0.31)$ \\
\hline Chondrosarcoma & 7 & 0.17 \\
\hline Other sarcomas & 2 & 0.05 \\
\hline Granular cell tumor & 7 & 0.17 \\
\hline Neurinoma & 3 & 0.07 \\
\hline Astrocytoma & 6 & 0.15 \\
\hline Pituicytoma & 3 & 0.07 \\
\hline Ganglioglioma & 1 & 0.02 \\
\hline Neurocytoma & 1 & 0.02 \\
\hline Suprasellar germinoma & 6 & 0.15 \\
\hline Gliomatous tumor, not classified & 1 & 0.02 \\
\hline Histiocytosis of Langerhans & 2 & 0.05 \\
\hline Neuroendocrine tumor, not classified & 1 & 0.02 \\
\hline Malignant lymphoma & 1 & 0.02 \\
\hline Fibroma & 2 & 0.05 \\
\hline Hemangioma & 3 & 0.07 \\
\hline Hamartoma & 3 & 0.07 \\
\hline Fibrous dysplasia & 4 & 0.1 \\
\hline Rathke's cyst & 76 & 1.8 \\
\hline Colloid cyst & 15 & 0.36 \\
\hline Arachnoidal cyst & 9 & 0.22 \\
\hline Epidermoid cyst & 10 & 0.24 \\
\hline Cyst, not classified & 5 & 0.12 \\
\hline Mucocele & 2 & 0.05 \\
\hline Plasma cell granuloma & 1 & 0.02 \\
\hline Granulation tissue & 3 & 0.07 \\
\hline Lymphocytic hypophysitis & 14 & 0.34 \\
\hline Granulomatous hypophysitis & 6 & 0.14 \\
\hline $\begin{array}{l}\text { Granulomatous hypophysitis in } \\
\text { generalized disease }\end{array}$ & 1 & 0.02 \\
\hline Tuberculous hypophysitis & 1 & 0.02 \\
\hline Peritumorous hypophysitis & 2 & 0.05 \\
\hline Abscess & 10 & 0.24 \\
\hline Chronic inflammation, not classified & 9 & 0.22 \\
\hline Necrosis & 2 & 0.05 \\
\hline Fibrosis or scar & 17 & 0.4 \\
\hline Hyperplasia of ACTH cells & 4 & 0.1 \\
\hline Hyperplasia of prolactin cells & 6 & 0.15 \\
\hline Hyperplasia of GH cells & 2 & 0.05 \\
\hline Hyperplasia of $\mathrm{FSH} / \mathrm{LH}$ cells & 1 & 0.02 \\
\hline Castration cells & 2 & 0.05 \\
\hline Crooke cells (without adenoma) & 76 & 1.84 \\
\hline Normal pituitary & 53 & 1.3 \\
\hline No diagnosis (insufficient specimens) & 13 & 0.32 \\
\hline Sum & 4122 & 100 \\
\hline
\end{tabular}

\section{Proliferation markers for pituitary tumors}

For evaluation of the proliferative activity of the pituitary tumor, both counting of mitoses and immunostaining of nuclei for proliferation markers may be used. Mitoses are rarely seen in non-invasive adenomas ( $3.9 \%$ of cases), but more frequently demonstrated in invasive adenomas $(21.4 \%)$ and carcinomas (66.7\%) (10). Concerning the mitotic index, the highest values $(0.09 \pm 0.035 \%)$ are found in pituitary carcinomas, without any clear differences between invasive $(0.013 \pm 0.005 \%)$ and non-invasive $(0.02 \pm 0.002 \%)$ adenomas $(10)$. Therefore, a critical index cannot be defined. In an own study (11), the mitotic index correlated to DNA aneuploidy of adenomas. Ki-67 (MiB-1) as the most important proliferation marker is expressed in the G1, S, G2, and M phases of the cell cycle. In an early study of 1987 (12), biopsy specimens of 31 pituitary adenomas representing all major endocrine types harbored immunoreactive nuclei to Ki-67 ranging from 0.1 to $3.7 \%$. Eleven hormonally inactive adenomas demonstrated Ki-67 values in the lower range $(0.1-1.0 \%)$, whereas six acromegalic patients presented with Ki-67 levels in the upper range (1.1$1.5 \%)$. The percentages of Ki-67-positive cells in 12 prolactinomas and two adenomas from patients with Cushing's disease covered the entire range (0.1-3.7\%). Preoperative bromocriptine treatment of prolactinomas did not influence Ki-67 expression. In a more recent study (13), Ki-67 (MiB-1) was positive in 139 of 159 adenomas (87\%). The Ki-67 index ranged from 0.16 to $15.48 \%$ $($ mean \pm S.D. $=1.22 \pm 2.09 \%)$ and was higher in ACTHsecreting adenomas. Invasive pituitary adenomas had a significantly higher Ki-67 index $(2.01 \pm 3.15 \%)$ than non-invasive adenomas with or without suprasellar extension (1.12 $\pm 1.87 \%)$. The index was not significantly different in the subgroup of adenomas with invasion of the cavernous sinus compared with groups with other types of invasion. Focusing on hormonally inactive pituitary adenomas, a study of our own material revealed a mean labeling index (LI) for MiB-1 of 0.12 (s.D. 0.29) in adenomas growing $<1.5 \mathrm{~mm} /$ year, and 0.34 (s.D. 1.05) in adenomas growing more than $1.5 \mathrm{~mm}$ (14). For non-invasive adenomas, the mean MiB-1 LI was 0.03 (s.D. 0.057), for invasive adenomas, it was $0.126(0.273)$, and for strongly invasive adenomas 0.212 (s.D. 0.393).

The mean MiB-1 LI was lower in null cell adenomas (LI 0.12, S.D. 0.25) than in FSH/LH adenomas (LI 0.63, S.D. 1.28). However, all these data did not reach statistical significance. Further markers (proliferating cell nuclear antigen (PCNA), Topoisomerase IIa, p27, and others $(15,16))$ may be used to analyze proliferation, but are generally not thought to be superior to Ki-67 (MiB-1), although in one of our own studies (14), PCNA was a more valuable marker of rapidity of tumor growth and confirmed the significance of p53 protein expression for invasive adenomas.

\section{p53 expression as a marker of pituitary adenomas}

The product of the tumor suppressor gene p53, p53 protein was found to be useful for the identification of recurrent pituitary adenomas in childhood and adolescence. Its expression correlates with invasive behavior (17), with immunostaining of p53 limited to invasive 
adenomas in our own studies (14). Whereas, we did not find any correlations to the clinical growth rate, p53 expression correlated significantly with the numbers of MiB-1-positive nuclei $(P=0.002)$ and PCNA-positive nuclei $(P=0.0027)$.

\section{Invasiveness as a marker of pituitary adenomas}

Enclosed adenomas have a clear delineation to the remaining pituitary tissue, the sellar floor bone, the cavernous sinus, and the diaphragm. In contrast, invasive adenomas are defined by their growth into one or more of these surrounding tissues, mostly in the form of small adenoma cell nests. Although defined as benign tumors, nearly $50 \%$ of pituitary adenomas invade surrounding tissues (18). Invasion of sellar bone may easily be demonstrated in surgical specimen, invasion of the dura is best found histologically in special dural surgical specimens (19). The frequency of dural invasion was found to increase with the size of the pituitary adenoma, as measured on MRI (19). Invasion should be demonstrated preoperatively by neuroimaging with MRI (20). The rate of invasiveness differs between the various pituitary adenoma types (Table 3). By far, the lowest rate of invasive adenomas was observed for Cushing's disease (13\%), followed by GH- and PRL-expressing adenomas, null cell, and plurihormonal adenomas (31-52\%) (21). In contrast, the other types (ACTH cell adenomas in Nelson's syndrome, inactive ACTH cell adenomas, FSH/LH cell adenomas, and TSH cell adenomas) demonstrated invasion of surrounding structures in the majority of tumors investigated (82-100\%; Table 3) (22). Invasive pituitary adenomas are generally characterized by a higher Ki-67 proliferation index $(13,14)$. In addition, invasive adenomas may demonstrate p53-positive nuclei, which were found to be absent in enclosed adenomas (14, 23, 24). The molecular mechanisms controlling cell proliferation and invasion are largely unknown, but are believed to be separate from each other (25). Invasiveness of the pituitary adenomas was established as a prognostic factor. It is feasible that the invasion of surrounding tissue may hinder complete surgical resection and for this reason, residual tumor tissue after pituitary surgery was more frequently demonstrated in patients with invasive adenomas significantly than in those with non-invasive adenomas (19). Furthermore, the survival rate at 6 years postsurgery was slightly but significantly decreased for patients with dural invasion (19).

\section{Tumor size as a marker of pituitary adenomas}

Both the proliferation rate and the ability to invade into the surrounding tissue will determine the size of a pituitary tumor at the time of diagnosis. However, due to the endocrine hyperfunction, hormonally active adenomas are usually diagnosed at an earlier stage than hormonally inactive tumors, the latter being diagnosed mostly due to the effect of local pressure exerted by the already existing large tumor. In our registry (Table 3), $15-86 \%$ of macroadenomas occur among hormonally active tumors compared with $95-100 \%$ in the group of typical hormonally inactive tumors. Other factors like treatment strategies may also influence the size of the tumor at the time of operation. Interestingly, the tumor size at diagnosis may point to specific aspects in the pathogenesis of certain pituitary adenomas. Careful studies of the case history of patients with

Table 3 Size and rate of invasiveness of surgically resected pituitary adenomas $(18,21)$.

\begin{tabular}{|c|c|c|}
\hline Adenoma type & Rate of macroadenomas $(>1.0 \mathrm{~cm})$ & Rate of invasiveness \\
\hline $\begin{array}{l}\text { Densely granulated GH cell adenoma } \\
\text { Sparsely granulated GH cell adenoma }\end{array}$ & $86 \%$ & $52 \%$ \\
\hline Densely granulated prolactin cell adenoma & $74 \%$ & $50 \%$ \\
\hline Sparsely granulated prolactin cell adenoma & $50 \%$ & \\
\hline Mixed GH/prolactin cell adenoma & $74 \%$ & $31 \%$ \\
\hline Mammosomatotrope adenoma & $50 \%$ & \\
\hline \multicolumn{3}{|l|}{$\begin{array}{l}\text { Densely granulated ACTH cell adenoma } \\
\text { Sparsely granulated ACTH cell adenoma }\end{array}$} \\
\hline Morbus Cushing & $15 \%$ & $13 \%$ \\
\hline Nelson's syndrome & $100 \%$ & $82 \%$ \\
\hline Inactive & $100 \%$ & $82 \%$ \\
\hline Crooke cell adenoma & $75 \%$ & $85 \%$ \\
\hline TSH cell adenoma & $100 \%$ & $100 \%$ \\
\hline FSH/LH cell adenoma & $95 \%$ & $95 \%$ \\
\hline Null cell adenoma, oncocytic variant & $95 \%$ & $?^{\mathrm{b}}$ \\
\hline Plurihormonal adenoma & $75 \%$ & $52 \%$ \\
\hline Silent adenoma (subtype 3) & $100 \%$ & $100 \%$ \\
\hline
\end{tabular}

aseries too small for significant data.

${ }^{\mathrm{b}}$ No reliable data. 
microprolactinomas who refused treatment revealed a low risk of approximately $6.5 \%$ up to $10 \%$ for progression to macroprolactinomas (26-29). These may therefore be considered two separate disease entities. Clearly, tumor size is a relevant prognostic marker for the success of any treatment. Surgical outcome was found to be better in patients with microadenomas of various types as compared with macroadenomas of these types (30-32). Primary medical treatment of GH-secreting pituitary adenomas with somatostatin analogs was more efficacious in microadenomas compared with macroadenomas (33). Generally, larger tumors recur more frequently than smaller adenomas after surgery. The highest recurrence rate $(19 \%)$ was found in patients with inactive macroadenomas with a follow-up of more than 2 years (34).

\section{Expression of specific hormones as markers of pituitary tumors}

The WHO classification of $2004(9,35,36)$ is based on the structural similarities with normal parenchymal cells and the immunohistochemical demonstration of hormone content. Thereby, pituitary adenomas may express more than one or two hormones. The bihormonal-bicellular character of the combination of GH and PRL is problematic due to the common stem cells, the existence of mammosomatotrope cells in the normal pituitary and the transition between both the cell types $(37,38)$. Nevertheless, three different bihormonal GHand PRL-secreting adenoma types were again specified in the new WHO classification (9). The combination of FSH and LH is considered as bihormonal but not as bicellular since both hormones are always produced in the same cell type (39). Plurihormonal adenomas may be monomorphous showing only one cell type or may be plurimorphous showing more than one cell type. Some plurihormonal adenomas do not reveal any real similarities with normal pituitary cells. Two types of monohormonal (densely or sparsely granulated) $\mathrm{GH}$-secreting adenomas are distinguished, three types of adenomas producing GH and PRL, and two types secreting PRL only (Table 4). Adenomas producing

Table 4 Pathohistological classification of pituitary adenomas.

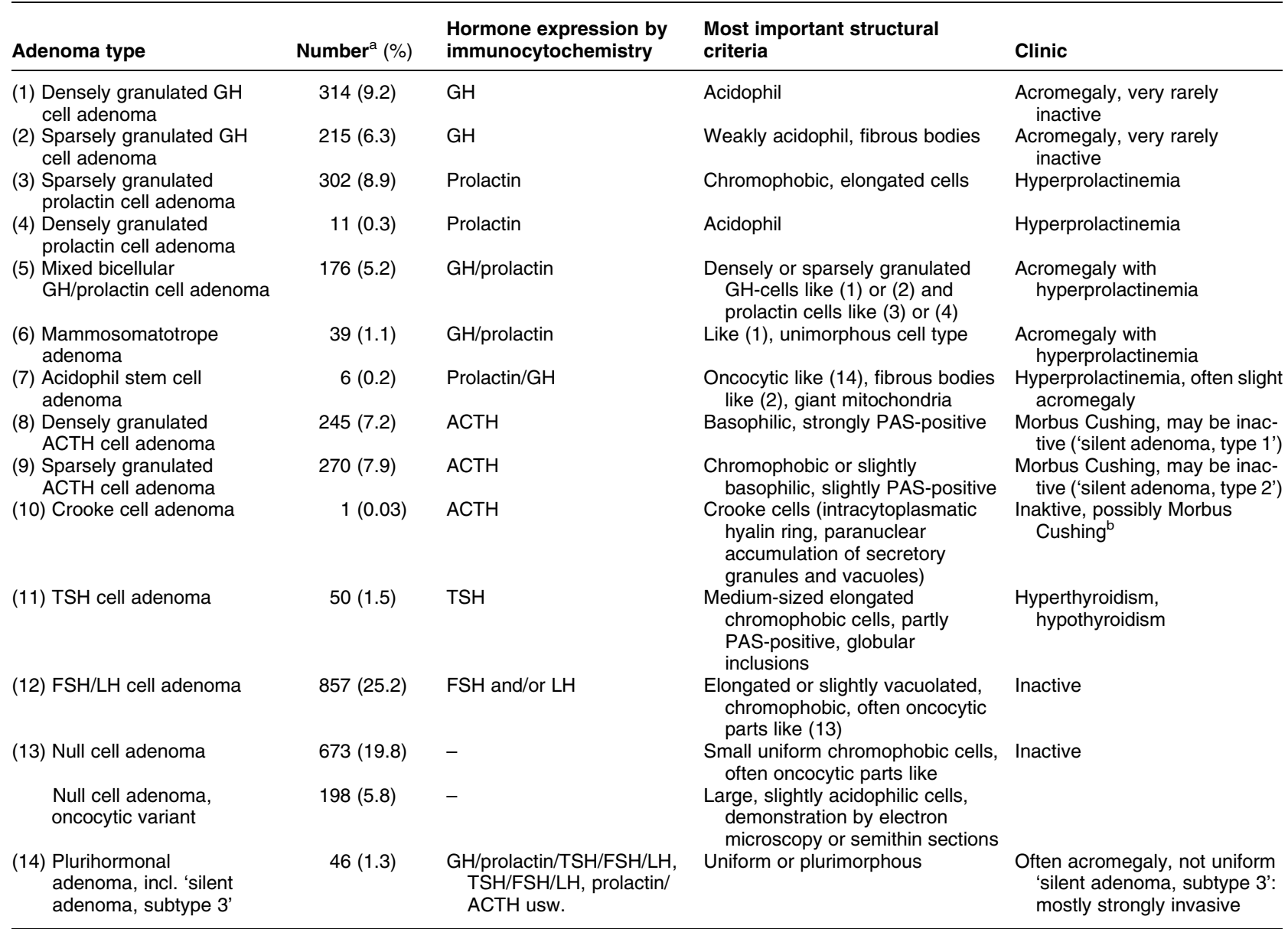

${ }^{a}$ Collection in the German Registry of Pituitary Adenomas of the years 1996-2005 $(N=3403$; without unclassified adenomas ( $N=74)$, atypical adenomas $(N=12)$, and pituitary carcinomas $(N=5))$.

${ }^{\mathrm{b}}$ No significant results due to small number of cases. 
ACTH can be active or inactive, densely or sparsely granulated, and very rarely of the Crooke cell type. Adenomas secreting TSH may be either pure TSH cell adenomas or belong to the group of plurihormonal adenomas. Pituitary adenomas expressing hormones may differ in their ability and quantity of hormone secretion, as well as in the functional integrity of the hormones secreted. Without typical clinical symptoms, such pituitary adenomas are termed silent. Typical inactive tumors are the FSH/LH cell adenomas and the null cell adenomas. In our series, $66.5 \%$ are monohormonal, $6.5 \%$ are bihormonal for $\mathrm{GH}$ and PRL, $1.3 \%$ are plurihormonal, and $25.6 \%$ do not express any hormones (Table 4). Even with such a sophisticated classification based on the experiences of many specialized pathologists around the world (9), a small percentage of adenomas ( $2.1 \%$ in our collection) cannot be classified. Technical problems related to small specimens, artifacts, and necroses of the cells are one obvious reason, while very unusual structures may prevent classification in other samples. In acromegaly, the most important prognostic factor was found to be the invasiveness of the adenoma which can be predicted by MRI and definitely proved by a thorough intraoperative inspection with adequate visualization methods. Therefore, the differentiation of resectable and incompletely resected or non-resectable adenomas is clinically relevant (31). This decision is made by the surgeon and not on the basis of tissue investigations.

\section{Adenomas secreting only GH}

The densely granulated GH cell adenoma $(9.2 \%$ of adenomas in our collection; Table 4) has a diffuse pattern. The cells are slightly pleomorphic, large- or medium-sized, partly angular, and mostly strongly acidophilic. The nuclei show small- to medium-sized nucleoli and moderate chromatin. Binucleated cells can be observed. Mitoses are very rare, and $<3 \%$ of nuclei are MiB-1-positive. Immunostaining for $\mathrm{GH}$ is strong and diffuse. In the electron microscope $(6,40)$, the similarity of adenoma cells with normal GH cells is evident. Medium-sized (300-450 nm) secretory granules are numerous. The rough endoplasmic reticulum is moderately developed and the Golgi fields are spherical. In general, densely granulated $\mathrm{GH}$ cell adenomas are slow-growing and usually well-demarcated tumors, with a relatively low rate of invasion (40). In contrast, the sparsely granulated GH cell adenoma $(6.3 \%$ of adenomas in our collection; Table 4) shows a more diffuse growth pattern. The cells are medium-sized or large, and slightly acidophilic. The nuclei are often pleomorphic and rich in chromatin. The cytoplasm exhibits a paranuclear spherical clear zone with strong keratin expression. These fibrous bodies are the hallmark of this adenoma type. The GH immunoreaction is weaker than in the densely granulated type, and may be negative in some cases (41). In the latter case, the staining should be repeated, possibly using other GH antibodies. Furthermore, in situ hybridization may be used in cases of strong clinical suspicion to detect GH mRNA, which will be positive in sparsely granulated GH cell adenomas $(42)$. Some $(<10 \%)$ cells may be positive for PRL. The number of MiB-1-positive nuclei is between 0 and $3 \%$. Evaluation of the ultrastructure reveals a different pleomorphism of nuclei organelles (6). The rough endoplasmic reticulum may be more prominent and forming nebenkerns. The secretory granules are sparse, mostly small and pleomorphic. The fibrous bodies are composed of dense aggregates of type II filaments (43). Increased hormone secretion (44), proliferation (45), and recurrence after surgery (46) of sparsely granulated $\mathrm{GH}$ adenomas in comparison with densely granulated adenomas have been claimed by some authors, but disputed by others (47).

\section{Alterations after treatment with somatostatin} analogs Treatment with somatostatin analogs results in tumor shrinkage in $40-50 \%$ of patients, especially in those with receptors for somatostatin (48). Frequent histological findings are perivascular and interstitial fibroses, an increased acidophilia of cells, stronger GH immunoreaction, and a lower MiB-1 index (49).

\section{Prolactin-secreting adenomas}

The densely granulated PRL cell adenoma is a very rare adenoma type $(0.3 \%$ in our collection; Table 4$)$. It contains elongated acidophilic cells with elongated nuclei and increased chromatin. Immunoreaction for PRL is strong and diffuse. The electron microscope reveals large, in part densely arranged secretory granules with exocytoses and a strongly developed rough endoplasmic reticulum (6). The sparsely granulated PRL cell adenoma (8.9\% in our collection; Table 3) has a medullary-diffuse, trabecular or pseudopapillary growth pattern and is composed of large, often elongated chromophobic cells with oval large moderately chromatin-rich nuclei. Calcifications of psammoma body type can be found. Amyloid derived from PRL (endocrine amyloid) is demonstrable in up to $48 \%$ of adenomas $(50,51)$. Immunostaining for PRL is often concentrated in the Golgi areas (so-called Golgi pattern) (6, 40). The MiB-1 index is low. In the electron microscope, we find slightly lobated nuclei, a very strongly developed rough endoplasmic reticulum with long membranes partly forming nebenkerns, large Golgi fields, and sparse, mostly small (100-300 nm) secretory granules. A characteristic feature is the demonstration of exocytoses into the intercellular space (52). Although prolactinomas are the most frequent pituitary adenomas, their frequency in surgical material is decreasing due to their preferential medical treatment. PRL hypersecretion is always 
present in these patients and clearly correlates with the size of the adenoma (53).

Effects of treatment with dopamine agonists Dopaminergic drugs induce a strong shrinkage of adenoma cells in most cases correlating to the strong decrease of PRL levels $(40,54)$. The cytoplasm is reduced and the rough endoplasmic reticulum and the Golgi fields are strongly decreased (55). The number of single necrotic cells and, after long-term treatment, the amount of fibroses are increased (56).

\section{Adenomas secreting both GH and prolactin}

The bicellular-bihormonal GH/PRL cell adenoma (5.2\% in our series; Table 4) is composed of sparsely or densely granulated cells that correspond to the sparsely or densely granulated cells of the GH cell adenomas, and of sparsely granulated PRL cells that we find otherwise in sparsely granulated PRL cell adenomas. Additionally, some adenoma cells may contain both GH and PRL (52). The ultrastructure exhibits adenoma cells of the GH cells type and of the PRL cell type (57). In contrast, the monocellular bihormonal mammosomatotrope adenoma ( $1.1 \%$ in our collection; Table 4$)$ is composed of medium-sized to large strongly acidophilic cells in a medullary or diffuse arrangement resembling the densely granulated GH cell adenoma. The immunoreaction for $\mathrm{GH}$ is strong in most cells, whereas the immunoreaction for PRL is mostly weak in the same cells. The MiB-1 index is very low. The ultrastructure is very similar to densely granulated $\mathrm{GH}$ cell adenomas, although the secretory granules are larger and more irregular (57). Exocytoses into the intercellular space are demonstrable. The acidophil stem cell adenoma $(0.2 \%$ in our collection; Table 4$)$ is a monomorphous monohormonal adenoma secreting PRL or a monomorphous bihormonal adenoma secreting mostly PRL and less GH. The growth pattern is diffuse. The cells are slightly pleomorphic, weakly acidophilic, and PAS-negative. Large clear cytoplasmic vacuoles are demonstrable which correspond to giant mitochondria. Furthermore, the mitochondria are increased in number comparable with oncocytic adenomas. Fibrous bodies are found similar to the sparsely granulated $\mathrm{GH}$ cell adenomas. Immunostaining for PRL is variable and the reaction for $\mathrm{GH}$ is weak. The MiB-1 index is not increased. The ultrastructure shows giant mitochondria, increased numbers of mitochondria, fibrous bodies, and other structures of sparsely granulated $\mathrm{GH}$ cell adenomas but also structures of PRL cell adenomas. The acidophil stem cell adenoma is more aggressive than other adenomas, always invasive (40), and mostly resistant to drug treatment (6). Clinically, GH-PRL adenomas with the exception of acidophil stem cell adenomas are characterized by acromegaly or gigantism as well as varying degrees of hyperprolactinemia
(40). An increased frequency and higher levels of PRL secretion have been demonstrated in GH-PRL adenomas compared with GH adenomas (58). The authors suggest that PRL levels above $200 \mathrm{ng} / \mathrm{ml}$ in combination with autonomous GH secretion indicate indeed GH-PRL adenomas.

\section{ACTH-secreting adenomas in Cushing's disease or Nelson's syndrome}

Densely granulated ACTH cell adenomas represent $7.2 \%$ of all adenoma types (Table 4 ). They show a medullary, diffuse, or sinusoidal growth pattern. The cells are monomorphic, partly elongated, basophilic, and show a dense PAS-positive granulation. Cellular or nuclear pleomorphism is generally low but may be demonstrable in some cases. Immunostaining reveals strong reactions for ACTH. Other peptides derived from proopiomelanocortin may also be found, and in some cases, $\boldsymbol{\alpha}$-subunit or galanin $(59,60)$. Electron microscopy shows monomorphic spherical or ovoid nuclei with distinct nucleoli, a moderately developed rough endoplasmic reticulum, spherical medium-sized Golgi fields and numerous slightly pleomorphic secretory granules with diameters between 200 and $450 \mathrm{~nm}$. In Cushing's disease, cytokeratin filaments are numerous and may form bundles near the nuclei, probably in reaction to the hypercortisolism. In Nelson's syndrome, these cytofilaments are lacking or sparse (61). Sparsely granulated ACTH cell adenomas occupy $7.9 \%$ of our registry (Table 4). Due to their low granulation, sparsely granulated ACTH cell adenomas are only weakly basophilic and weakly PAS-positive or chromophobic. Cellular pleomorphism is more frequent in the sparsely granulated than in the densely granulated type. Immunostaining is nearly identical with the densely granulated ACTH cell type, although the reactions especially for ACTH are weaker and may be negative. In the latter case, when clinical suspicion appears justified, more than one antibody for ACTH should be tried for differentiation from other adenoma types, especially from the inactive adenomas of the null cell type. The electron microscopy reveals far less numerous and often smaller secretory granules than in the densely granulated ACTH cell adenomas, whereas the organelles structures are similar or slightly irregular. Clinically, ACTH cell adenomas are associated with pituitary-dependent Cushing's disease. Most adenomas are of small size (Table 2). Due to the very small size of some adenomas, tissue that represents the true nature of the lesion may be lost during surgical procedures, so that the specimens contain only pituitary tissue with Crooke cells (about 50 cases in our series; Table 2) or the adenoma tissue submitted is too small for cutting enough slides for immunohistological classification. This is the main reason for 74 unclassified tumors (2.2\%; Table 4) in our collection. Adenomas associated with Nelson's syndrome are usually large 
with an aggressive, invasive behavior, and a high rate of recurrences after surgery $(44,62)$. In contrast to most other hormonally active pituitary adenomas, there is no relationship between the severity of hypercortisolism, the plasma ACTH levels, and the tumor size (58).

Peritumorous pituitary in active ACTH cell adenomas In the presence of an active ACTH cell adenoma in Cushing's disease, the adenohypophysis shows characteristic alterations of the ACTH cells that were first described by Crooke (63) and called Crooke cells. These cells are larger than normal ACTH cells and exhibit an intracytoplasmic hyaline ring, paranuclear vacuoles, and secretory granules beside the vacuoles and along the cellular membrane. In the electron microscope, the hyaline ring is composed of dense keratin filaments and the vacuoles are large lysosomes that take up the secretory granules $(64,65)$. These cells develop in hypercortisolemic states of all types (drugs, adrenal Cushing's syndrome, active ACTH cell adenomas, and paraneoplastic ACTH syndrome). If Crooke cells are not demonstrable in pituitaries with ACTH cell adenomas, these adenomas are considered inactive adenomas $(64,66)$ or represent adenomas in Nelson's Syndrome. In our collection, we found Crooke cells in all cases of active ACTH cell adenomas where sufficient specimens and paraadenomous pituitary tissue were available.

\section{Clinically inactive (silent) ACTH cell adenomas}

Two subtypes of inactive ACTH cell adenomas are identified. Furthermore, the rare Crooke cell adenoma may be inactive. The silent densely granulated ACTH

Table 5 Clinically silent and inactive pituitary adenomas (surgical specimens of sellar region, 1991-2005; $N=2012$ ).

\begin{tabular}{lrc}
\hline Adenoma type & Number & Percentage (\%) \\
\hline Null cell adenoma & 678 & 33.7 \\
$\quad$ Null cell adenoma, oncocytic & 216 & 10.7 \\
$\quad$ variant & 865 & 43.0 \\
FSH/LH cell adenoma & 31 & 1.5 \\
Prolactin cell adenoma, sparsely & & \\
$\quad$ granulated & 3 & 0.15 \\
Prolactin cell adenoma, densely & & \\
$\quad$ granulated & 19 & 0.94 \\
GH cell adenoma, sparsely & 1 & 0.05 \\
$\quad$ granulated & 1 & 0.05 \\
Mixed GH/prolactin cell adenoma & 89 & 4.4 \\
Acidophil stem cell adenoma & & \\
ACTH cell adenoma, sparsely & 22 & 1.1 \\
$\quad$ granulated & & 0.9 \\
ACTH cell adenoma, densely & 18 & 1.8 \\
$\quad$ granulated & 36 & 1.6 \\
TSH cell adenoma & 33 & 100 \\
Plurihormonal adenoma & 2011 & \\
Unclassified adenoma & & \\
Sum & & \\
\hline
\end{tabular}

adenoma is also designated as subtype 1 adenoma (52). The incidence in our collection of clinically silent and inactive adenomas is $1.1 \%$ (Table 5 ). It is histologically and ultrastructurally indistinguishable from active densely granulated ACTH cell adenomas. The incidence of spontaneous hemorrhagic necroses is higher than in the active ones (40). The second inactive ACTH adenoma is the silent sparsely granulated adenoma and is called subtype 2 adenoma in the Kovac's classification (52). Its incidence in our collection of clinically silent and inactive adenomas is $4.4 \%$ (Table 5). Most patients are men. The tumor shows very similar structures to the active sparsely granulated ACTH cell adenoma and is indistinguishable from that if clinical data or adjacent tumor-free tissue for the identification of Crooke cells are not available. The ultrastructure of the organelles may be slightly more pleomorphic than in the active ones. Crooke cell adenomas are very rare $(0.03 \%$ of all adenoma types in our registry; Table 4). They are composed of Crooke cells with typical cytoplasmatic structures (hyaline ring of densely arranged microfilaments, large lysosomes, secretory granules around the lysosomes, and at the cell periphery). Some adenoma cells are not completely transformed to Crooke cells showing less microfilaments. Whereas, ACTH hyperfunction is observed in $65 \%, 35 \%$ are clinically inactive (67). The clinical course is variable, with some tumors demonstrating an aggressive behavior, and others only being found as small incidental inactive adenomas in postmortem pituitaries (68). In a recent study, invasiveness was found in $72 \%$ of these adenomas (67).

\section{TSH cell adenoma}

TSH cell adenomas are not frequent $(1.5 \%$ in our collection; Table 4). By far, most of the adenomas of this type are invasive macroadenomas $(69,70)$. Light microscopy reveals sinusoidal growth pattern. The cells are medium-sized and chromophobic. They may harbor globular PAS-positive inclusions representing lysosomes. Immunostaining for TSH is varying, mostly slight, but may be negative (71), although others found a conclusive immunoreactivity for TSH (40). The ultrastructure is characterized by distinct similarities to normal TSH cells with often prominent rough endoplasmic reticulum, globoid Golgi complexes, and sparse small (150-250 nm), rod-shaped or spherical or irregular secretory granules (71). TSH cell adenomas are hyperfunctioning for TSH in about $42 \%$ of patients, but may also be found in euthyroid patients. They can develop in patients with long-standing hypothyroidism and may be accompanied and/or preceded by TSH cell hyperplasia (72). High levels of TSH and peripheral thyroid hormones in these patients must be differentiated from inappropriate secretion of TSH due to peripheral resistance to thyroid hormones. 


\section{Non-functioning pituitary adenomas}

Patients with non-functioning pituitary tumors have no obvious symptoms related to a hormone excess except for mild hyperprolactinemia in some cases. The latter is thought to result from compression of the pituitary stalk by the tumor, leading to interference with the PRL-inhibiting dopamine transport. Due to the absence of hormone-related symptoms, non-functioning adenomas are usually large at the time of diagnosis. However, with an increasing frequency of radiological evaluations of the CNS for unrelated reason, pituitary adenomas are detected more frequently than in the past. Most of these incidental findings are non-functioning adenomas (7). In our registry, $12.6 \%$ of all clinically inactive adenomas are silent adenomas, which are characterized by the insufficient secretion of active hormones into the circulation, despite their expression (Table 5). Most of these are ACTH cell adenomas (Table 5), which are described earlier. Next in frequency are plurihormonal adenomas, sparsely granulated PRL cell adenomas, TSH cell adenomas, and sparsely granulated GH cell adenomas (Table 5). In contrast to these, $87.4 \%$ of clinically inactive adenomas are adenomas of the null cell type or $\mathrm{FSH} / \mathrm{LH}$ type. Importantly, other sellar masses should be considered in the differential diagnosis of these adenomas, as described later. FSH/LH adenomas are the most frequent non-functioning adenoma type representing $25.2 \%$ in our total collection (Table 4 ) and $43 \%$ of inactive adenomas (Table 5) respectively. They exhibit a mostly sinusoidal growth pattern, and may develop pseudorosettes and microfollicles. The cells are relatively large, partly cylindrical PAS-negative and chromophobic. Some very small PAS-positive granules may be demonstrable. Immunostaining varies in proportions and intensities. In most of these adenomas, both FSH and LH are demonstrable, with isolated expression of FSH second, and LH third. In addition, $\alpha$-subunit may be expressed. Evaluation of the ultrastructure reveals that many adenomas are similar to oncocytic adenomas or null cell adenomas, whereas others show distinct similarities with normal gonadotrope cells. The rough endoplasmic reticulum may be dilated, but the structures of so-called castration cells are not found (73). Secretory granules are sparse and very small. FSH-LH cell adenomas of female patients often exhibit honeycomb Golgi fields with characteristic vacuolar transformations $(52,74)$, and these may also be found in ACTH cell adenomas (75). Elevated levels of gonadotropins in the blood circulation are found in approximately $25 \%$ of patients with non-functioning pituitary adenomas. However, the levels of LH and FSH in the blood circulation do not correlate with the expression of these hormones (76). Null cell adenomas represent $25.6 \%$ of our collection (Table 4) and 33.7\% of all inactive adenomas respectively (Table 5). A sinusoidal or diffuse growth pattern is characteristic for this adenoma type. Some pseudorosettes may be present. The small- to medium-sized monomorphic cells are chromophobic. Generally, hormones are not demonstrable but focal staining (in not more than $5-10 \%$ of cells) for FSH, LH, or $\alpha$-subunit may be found. In one series (77), occasional cells immunopositive for $\mathrm{GH}$, PRL, and ACTH were additionally demonstrable in 18\% of null cell adenomas. The variably strong expression of chromogranin A (78) can be used if difficulties in the differential diagnosis to lymphomas or meningiomas exist. The electronmicroscope $(6,52)$ reveals polyhedral small- to medium-sized cells with irregularly outlined nuclei and sparse organelles. Rough endoplasmic reticulum and Golgi fields are poorly developed. The secretory granules are small and spherical, and randomly distributed. The number of mitochondria varies and transitions to oncocytes are not rare but should be limited to less than $50 \%$ of adenoma cells ( 79 , 80). Oncocytic adenomas are a variant of the null cell adenoma (WHO classification: null cell adenoma, oncocytic variant) and like the null cell adenomas are presumably derived from gonadotropic cells. In our collection, $5.8 \%$ of adenomas are such null cell adenomas of the oncocytic variant (Table 4). In the group of inactive adenomas, they represent 10.7\% (Table 5). They show a diffuse or sinusoidal architecture and rarely pseudorosettes. The cells are medium-sized or large, weakly acidophilic or chromophobic. The nuclei may be rich in chromatin. Immunostainings for pituitary hormones are negative, although sparse FSH, LH, or $\alpha$-subunit-positive cells may be demonstrable. Chromogranin A is expressed (78). Semithin sections of Eponembedded specimens reveal a typical granular or cloudy structure basing on densely arranged mitochondria. In the electron microscope, by far most adenoma cells show many, in part densely arranged mitochondria. The cristae may be slightly pleomorphic. The rough endoplasmic reticulum is sparse and the Golgi areas are small. Secretory granules are sparse and of different size. In our collection, 14 adenomas $(0.5 \%)$ express $\alpha$-subunit only, but no complete pituitary hormones like FSH or LH, as determined by immunocytochemistry. They had been designated as $\alpha$-subunit-only adenomas (81), but structurally they represent null cell adenomas and should be included in null cell adenoma type (Table 4).

\section{Plurihormonal adenomas}

With improved methods of immunostaining and the increased use of monoclonal antibodies, the incidence of plurihormonal adenomas is lower than expected from former studies with polyclonal antibodies (41). The plurihormonal adenoma type I corresponds light microscopically to densely granulated GH cell adenomas but expresses TSH, $\alpha$-subunit, and often FSH, LH, or PRL, in addition to GH. Ultrastructurally (57), the tumor reveals structures of densely granulated GH cell adenomas, or plurimorphous structures with predomination of the GH cell type. 
Table 6 Classification of atypical adenomas (surgical specimens of sellar region, 2005; $N=12 / 451$ ).

\begin{tabular}{lc}
\hline Adenoma type & Number \\
\hline Atypical densely granulated GH cell adenoma & 1 \\
Atypical sparsely granulated GH cell adenoma & 2 \\
Atypical sparsely granulated prolactin cell adenoma & 1 \\
Atypical densely granulated ACTH cell adenoma & 1 \\
Atypical sparsely granulated ACTH cell adenoma & 2 \\
Atypical FSH/LH cell adenoma & 1 \\
Atypical null cell adenoma & 3 \\
Atypical plurihormonal adenoma & 1 \\
Sum & 12 \\
\hline
\end{tabular}

The plurihormonal adenoma type II is structurally very similar to gonadotrope adenomas but expresses either TSH or GH, or PRL, in addition to FSH, LH, and $\alpha$-subunit. Evaluation of the ultrastructure reveals plurimorphism (57). Another plurihormonal adenoma is the silent subtype 3 adenoma $(9,74,82,83)$ being immunoreactive not only for GH, PRL, and TSH but also for other hormones. In the electron microscope, this adenoma type shows characteristics of glycoprotein hormone-producing adenomas. The broad cytoplasm contains high amounts of rough and smooth endoplasmic reticulum and distinctly large Golgi fields. The sparse 100-200 nm secretory granules often accumulate in cytoplasmic processes (9). This unusual tumor exhibits aggressive behavior and poor prognosis due to its highly infiltrative growth, rapid progression, and high recurrence rate (9).

\section{Atypical adenomas}

In the WHO classification of $2004(35,36,84)$, a new adenoma entity was included designating a borderline or uncertain behavior. Although this may also be true for the subtype 3 adenoma, the atypical adenoma was defined as an invasive tumor with elevated mitotic index, an MiB-1 labeling index $>3 \%$, and an extensive nuclear immunostaining for $\mathrm{p} 53$. Brain invasion is not an agreed upon criterion of malignancy. It differs from pituitary carcinoma only in the lack of metastases. Atypical adenomas account for $2.7 \%(12 / 451)$ tumors in our registry, as evaluated for 2005 (Table 6). Different types of atypical adenomas can be distinguished in our collection, corresponding to the 'typical' adenomas (Table 6). Most frequent atypical adenomas were sparsely granulated $\mathrm{GH}$ cell adenomas, sparsely granulated ACTH cell adenomas, and null cell adenomas, but for significant data of incidence the number is too small. Atypical adenomas were found to have a poorer prognosis due to decreased operability by a higher degree of invasiveness, larger size, and accelerated growth (9).

\section{Pituitary adenomas in combination with neuronal choristoma (PANCH)}

In rare cases $(0.29 \%(14 / 4891)$ in our collection of the years 1991-2005), ganglion cell-containing tumorous lesions (gangliocytomas or neuronal choristoma) adjacent to a typical pituitary adenoma were demonstrable (Table 7). Often, these neuronal tumors are situated cap-like over the adenomas. The border between both tumors is mostly ill-defined. The neuronal lesions are composed of various numbers of ganglion cells. These are large and mature and contain abundant cytoplasm and Nissl granules. They can be immunostained for synaptophysin, neuron specific enolase, and neurofilament. In acromegaly, GHRH is demonstrable $(85,86)$. In the very rare cases with ACTH hyperfunction, CRH was expressed (87). Some accompanying glial cells are demonstrable (86). The ultrastructure reveals slightly lobated nuclei and a broad cytoplasm with numerous microvesicles. The rough endoplasmic reticulum is sparse but partly dilated. Small- to medium-sized secretory granules are sparse. The mitochondria may be (86) numerous. Induction of adenoma formation by production of hypothalamic-releasing hormones in developmental lesions, i.e., neuronal choristomas has been discussed for the pathogenesis of PANCH (86-88). Alternatively, it has been suggested that the ganglionic lesions are the result of metaplasia from adenoma cells (89). Most cases of PANCH have demonstrated a benign behavior like ordinary adenomas (40).

\section{Pituitary carcinomas}

Pituitary carcinomas are defined by the demonstration of metastases (9). Whether or not extensive invasion of the brain by a pituitary tumor is a further criterion for carcinomas is a matter of controversy (9). Pituitary carcinomas are a very rare neoplasm (about 100 tumors published to date). Most are ACTH- or PRL-secreting tumors. GH-positive (90) or inactive tumors develop rarely into carcinomas (91). Most pituitary carcinomas develop from invasive relapsing adenomas. The tumor, its

Table 7 Intrasellar gangliocytomas in combination with pituitary adenomas (surgical specimens of sellar region, 1991-2005; $N=4891$ ).

\begin{tabular}{lllc}
\hline Adenoma type & Gangliocytoma type & Hyperfunction & Number \\
\hline Sparsely granulated GH cell adenoma & GHRH gangliocytoma & Acromegaly \\
Sparsely granulated mixed GH/prolactin cell adenoma & GHRH gangliocytoma & Acromegaly \\
Sparsely granulated prolactin cell adenoma & Gangliocytoma with prolactin & Hyperprolactinemia \\
Densely granulated ACTH cell adenoma & expression & 4 \\
& CRH gangliocytoma & Morbus Cushing & 1 \\
\hline
\end{tabular}


Table 8 Pituitary carcinomas (surgical specimens of sellar region, 1970-2005; $N=7602$ ).

\begin{tabular}{llc}
\hline Carcinoma type & Hyperfunction & Number \\
\hline $\begin{array}{c}\text { Sparsely granulated ACTH } \\
\text { cell carcinoma }\end{array}$ & Morbus Cushing & 7 \\
$\begin{array}{c}\text { Sparsely granulated prolactin } \\
\text { cell carcinoma }\end{array}$ & Hyperprolactinemia & 3 \\
$\begin{array}{c}\text { Densely granulated GH cell } \\
\text { adenoma }\end{array}$ & $\begin{array}{c}\text { Acromegaly, later } \\
\text { inactive }\end{array}$ & 1 \\
$\begin{array}{c}\text { Sparsely granulated GH cell } \\
\text { adenoma }\end{array}$ & Acromegaly & 1 \\
\hline
\end{tabular}

connective tissues, and surrounding structures may be altered by previous surgery and/or radiation therapies in a way that enables tumor cells to invade vessels for metastatic spread. The light and electron microscopical structures of pituitary carcinomas are not much different from that of atypical adenomas. They show a higher index of Ki-67 and p53 protein, and a lower expression of p27 (92) in the primary tumor and in its metastases. Ras mutations can be found in PRL cell carcinomas (93). Increased PCNA index and c-erbB-2 membrane staining were demonstrated in sellar tumors and its metastasis (94). The structures of the metastases are mostly identical to the features of the primary tumor $(91,95)$. In our series of 7602 pituitary lesions since 1970, 12 carcinomas (Table 8) were collected. Seven could be classified as ACTH cell carcinomas, three as PRL cell carcinomas, and two as GH cell carcinomas $(90,91,95)$.

The prognosis of pituitary carcinomas is generally poor, although patients with long-term survival have been described (96). Due to the small number of cases, comparative studies of different treatment options are lacking.

\section{Differential diagnosis of pituitary adenomas}

Pituitary adenomas have to be differentiated from other tumors of the sellar region (Table 1), especially from meningiomas, chordomas, craniopharyngiomas, gliomas, lymphomas, metastases, and germinomas. In most cases, the correct diagnosis is easily established using hematoxylin-eosin-stained sections, but in some tumors additional immunostaining may be necessary (97, 98). Synaptophysin and neuron-specific enolase are expressed in all types of pituitary adenomas but chromogranin A or keratins as important and common markers for endocrine epithelial tissue may be negative.

\section{Conclusions}

The classification of pituitary adenomas represents different types with specific characteristics. A large national registry such as ours includes sufficient numbers of samples, so that all types of pituitary adenomas including very rare entities are present in a significant number. Furthermore, other entities to consider for the differential diagnosis of sellar masses are entered. In the long term, such registries may allow further correlation of pathohistological characterization with clinical data and prognosis to improve the diagnosis and therapy even for rare types of pituitary adenomas (15). A national registry like our institution that is open to all pathologists and neurosurgeons to send specimens for consultant studies is therefore important in improving the patient's care and answering scientific questions.

\section{Acknowledgements}

This work was mainly financed by Novartis Pharma $\mathrm{GmbH}$ (Nuremberg), Novo Nordisk Pharma GmbH (Mainz), Pfizer Pharma GmbH (Karlsruhe), and Ipsen Pharma GmbH (Ettlingen).

\section{References}

1 Ambrosi B, Faglia G \& Multicenter Pituitary Study Group, Epidemiology of pituitary tumors. In Pituitary Adenomas. New Trends in Basic and Clinical Research. Proceedings of the 5th European Workshop on Pituitary adenomas, Venice, pp 159-168. Eds G Faglia, P Beck-Peccoz, B Ambrosi, P Travaglini \& A Spada, Amsterdam: Excerpta Medica, 1991.

2 Gold EB. Epidemiology of pituitary adenomas. Epidemiologic Reviews 19813182.

3 Radhakrishnan K, Mokri B, Parisi JE, O’Fallon WM, Sunku J \& Kurland LT. The trends in incidence of primary brain tumors in the population of Rochester, Minnesota. Annals of Neurology 199537 67-73.

4 Chidiac RM \& Aron DC. Incidentalomas: a disease of modern technology. Endocrinology and Metabolism Clinics of North America 199726 233-253.

5 Molitch ME \& Russell EJ. The pituitary 'incidentaloma'. Annals of Internal Medicine 1990112 925-931.

6 Asa SL. Tumors of the Pituitary Gland Washington, DC: Armed Forces Institute of Pathology, 1998.

7 Buurman H \& Saeger W. Subclinical adenomas in postmortem pituitaries: classification and correlations to clinical data. European Journal of Endocrinology 2006154 753-758.

8 Aron DC \& Howlett TA. Pituitary incidentalomas. Endocrinology and Metabolism Clinics of North America 200029205.

9 Lloyd RJ, Kovacs K, Young WF Jr, Farrell WE, Asa SL, Trouillas J, Kontogeorgos G, Sano T, Scheithauer BW, Horvath E, Watson RE, Jr, Lindell EP, Barkan AL, Saeger W, Nosé V, Osamura RY, Ezzat S, Yamada S, Roncaroli F, Lopes MBS \& Vidal Ruibal S. Tumours of the pituitary gland. In Pathology and Genetics. Tumours of Endocrine Tumours, pp 9-48. Eds RA DeLellis, RV Lloyd \& PU Heitz, Lyon: International Agency for Research and Cancer (IARC), 2004.

10 Pernicone PJ \& Scheithauer BW. Invasive pituitary adenoma and pituitary carcinoma. In Diagnosis and Management Pituitary Tumors, pp 369-386. Eds K Thapar, K Kovacs, BW Scheithauer \& RV Lloyd, Totowa, NJ: Humana Press, 2001.

11 Lüdecke DK, Beck-Bornholt HP, Saeger W \& Schmidt W. Tumour ploidy in DNA histograms of pituitary adenomas. Acta Neurochirurgica (Wien, Oester.) 198576 18-22.

12 Landolt AM, Shibata T \& Kleihues P. Growth rate of human pituitary adenomas. Journal of Neurosurgery 198767 803-806. 
13 Pizarro CB, Oliveira MC, Coutinho LB \& Ferreira NP. Measurement of Ki-67 antigen in 159 pituitary adenomas using the MIB-1 monoclonal antibody. Brazilian Journal of Medical and Biological Research 200437 235-243.

14 Saeger W, Lüdecke B \& Lüdecke DK. Comparison of proliferation markers and clinical tumor growth in inactive adenomas. Endocrine Pathology 200415 264-265.

15 Saeger W. Pituitary tumors: prognostic indicators. Endocrine 2005 28 57-66.

16 Saeger W. Proliferation markers and cell cycle inhibitors in pituitary adenomas. In Molecular Pathology of the Pituitary, pp 110-126. Eds G Kontogeorgos \& K Kovacs, Basel: Karger, 2004.

17 Hentschel SJ, McCutcheon IE, Moore W \& Durity FA. P53 and MIB-1 immunohistochemistry as predictors of the clinical behavior of nonfunctioning pituitary adenomas. Canadian Journal of Neurological Sciences $200330215-219$.

18 Sautner D \& Saeger W. Invasiveness of pituitary adenomas. Pathology, Research and Practice 1991187 632-636.

19 Meij BP, Lopes MBS, Ellegala DB, Alden TD \& Laws ER. The longterm significance of microscopic dural invasion in 354 patients with pituitary adenomas treated with transsphenoidal surgery. Journal of Neurosurgery 200296 195-208.

20 Bonneville JF, Bonneville F \& Cattin F. Magnetic resonance imaging of pituitary adenomas. European Radiology 200515 543-548.

21 Scheithauer BW. The pituitary and sellar region. In Sternberg's Diagnostic Surgical Pathology, pp 521-556. Eds SE Mills, D Carter, JK Greenson, HA Oberman, VE Reuter \& MH Stoler, Philadelphia: Lippincott Williams \& Wilkins, 2004.

22 de Lellis RA \& Mangray S. The adrenal glands. In Sternberg's Diagnostic Surgical Pathology, pp 621-668. Eds SE Mills, D Carter, JK Greenson, HA Oberman, VE Reuter \& MH Stoler, Philadelphia: Lippincott Williams \& Wilkins, 2004.

23 Buckley N, Bates AS, Broome JC, Strange RC, Perrett CW, Burke CW \& Clayton RN. P53 protein accumulates in Cushing's adenomas and invasive non-functional adenomas. Journal of Clinical Endocrinology and Metabolism 199479 1513-1516.

24 Oliveira MC, Marroni CP, Pizarro CB, Pereira-Lima JF, BarbosaCoutinho LM \& Ferreira NP. Expression of p53 protein in pituitary adenomas. Brazilian Journal of Medical and Biological Research 2002 35 561-565.

25 Amar AP, Hinton DR, Krieger MD \& Weiss MH. Invasive pituitary adenomas: significance of proliferation parameters. Pituitary 1999 2 117-122.

26 Sisam DA, Sheehan JP \& Sheeler LR. The natural history of untreated microprolactinomas. Fertility and Sterility $1987 \mathbf{4 8} 67-71$.

27 Weiss MH, Teal J, Gott P, Wycoff R, Yadley R, Apuzzo ML, Giannotta SL, Kletzky O \& March C. Natural history of microprolactinomas: six-year follow-up. Neurosurgery 198312 180-183.

28 Nomikos P, Buchfelder M \& Fahlbusch R. Current management of prolactinomas. Journal of Neuro-Oncology 200154 139-150.

29 von Werder K, Fahlbusch R \& Rjosk H-K. Macroprolactinomas: clinical and therapeutic aspects. In Prolactin and Prolactinomas, pp 415-429. Eds G Tolis, H Stefanis, T Mountokalakis \& F Labrie, New York: Raven Press, 1983.

30 Mortini P, Losa M, Barzaghi R, Boari N \& Giovanelli M. Results of transsphenoidal surgery in a large series of patients with pituitary adenoma. Neurosurgery 200556 1222-1233.

31 Abe T \& Lüdecke DK. Effects of preoperative octreotide treatment on different subtypes of $90 \mathrm{GH}$-secreting pituitary adenomas and outcome in one surgical centre. European Journal of Endocrinology 2001145 137-145.

32 Nomikos P, Buchfelder M \& Fahlbusch R. The outcome of surgery in 668 patients with acromegaly using current criteria of biochemical 'cure'. European Journal of Endocrinology 2005152 379-387.

33 Colao A, Pivonello R, Rosato F, Tita P, Menis E, Barreca A, Ferrara R, Mainini F, Arosio M \& Lombardi G. First-line octreotide-LAR therapy induces tumour shrinkage and controls hormone excess in patients with acromegaly: results from an open, prospective, multicentre trial. Clinical Endocrinology 200664 342-351.
34 Auer LM \& Clarici G. The first 100 transsphenoidally operated pituitary adenomas in a non-specialised centre: surgical results and tumour-recurrence. Neurological Research 19857 153-160.

35 Fahlbusch R \& Buslei R. The WHO classification of pituitary tumours: a combined neurosurgical and neuropathological view. Acta Neuropathologica $200611186-87$.

36 Saeger W. Comment to the 2004 World Health Organization classification of pituitary tumors. Acta Neuropathologica (Wien) $200611164-65$.

37 Stefaneanu L, Kovacs K, Lloyd RV, Scheithauer BW, Young WF Jr, Sano T \& Jin L. Pituitary lactotrophs and somatotrophs in pregnancy: a correlative in situ hybridization and immunocytochemical study. Virchows Archiv. B, Cell Pathology Including Molecular Pathology 199262 291-296.

38 Li J, Stefaneanu L, Kovacs K, Horvath E \& Smyth HS. Growth hormone $(\mathrm{GH})$ and prolactin (PRL) gene expression and immunoreactivity in GH-and PRL-producing human pituitary adenomas. Virchows Archiv. A, Pathological Anatomy 1993422 193-201.

39 Pernicone PJ, Scheithauer BW, Horvath E \& Kovacs K. Pituitary and sellar region. In Histology for Pathologists, pp 1053-1074. Ed. SS Sternberg, Philadelphia, New York: Lippincott-Raven Publications, 1997.

40 Scheithauer BW, Horvath E, Lloyd RV \& Kovacs K. Pathology of pituitary adenomas and pituitary hyperplasia. In Diagnosis and Management Pituitary Tumors, pp 91-154. Eds K Thapar, K Kovacs, BW Scheithauer \& RV Lloyd, Totowa, NJ: Humana Press, 2001.

41 Saeger W, Wilczak P, Lüdecke DK, Buchfelder M \& Fahlbusch R. Hormone markers in pituitary adenomas: changes within last decade resulting from improved method. Endocrine Pathology 2003 14 49-54.

42 Tallen G, Saeger W, Fehr S, Uhlig H \& Lüdecke DK. Growth hormone-, prolactin-and $\alpha$-chorionic gonadotropin mRNA in pituitary adenomas by in situ-hybridization using different detection methods. Pathologia (Madrid) 199225 (Suppl 1) 84.

43 Nishioka H, Haraoka J \& Akada K. Fibrous bodies are associated with lower GH production and decreased expression of E-cadherin in GH-producing pituitary adenomas. Clinical Endocrinology 2003 $59768-772$.

44 Horvath E \& Kovacs K. Pathology of prolactin cell adenomas of the human pituitary. Seminars in Diagnostic Pathology 19863 4-17.

45 Riedel M, Saeger W \& Lüdecke DK. Grading of pituitary adenomas in acromegaly. Comparison of light microscopical, immunocytochemical, and clinical data. Virchows Archiv. A, Pathological Anatomy 1985407 83-95.

46 Robert F. Electron microscopy of human pituitary tumors. In Clinical Management of Pituitary Disorders, pp 113-131. Eds GT Tindall \& WF Collins, New York: Raven Press, 1979.

47 Trouillas J, Sassolas G, Guigard MP, Fonlupt P, Ansaneli-Naves L \& Perrin G. Relationships between pathological diagnosis and clinical parameters in acromegaly. Metabolism 1996 45 53-56.

48 Petersenn S, Heyens M, Lüdecke DK, Beil FU \& Schulte HM. Absence of somatostatin receptor type 2 A mutations and gip oncogene in pituitary somatotroph adenomas. Clinical Endocrinology $2000 \mathbf{5 2} 35-42$.

49 Stefaneanu L, Kovacs K, Horvath E \& Scheithauer BW. The adenohypophysis. In Molecular and Cellular Endocrine Pathology, pp 75-118. Eds L Stefaneanu, H Sasano \& K Kovacs, London: Arnold, 2000.

50 Röcken C, Uhlig H, Saeger W, Linke RP \& Fehr S. Amyloid deposits in pituitaries and pituitary adenomas: immunohistochemistry and in situ hybridization. Endocrine Pathology 19956 135-143.

51 Saeger W, Gerigk C, Missmahl HP \& Lüdecke DK. Amyloidablagerungen in Hypophysenadenomen. Polarisationsoptische, immunhistologische und elektronenmikroskopische Untersuchungen. Der Pathologe 19834 183-189.

52 Kovacs K \& Horvath E. Tumors of the Pituitary Gland Washington, DC: Armed Forces Institute of Pathology, 1986.

53 Randall RV. Pituitary adenomas associated with hyperprolactinemia: a clinical and immunohistochemical study of 97 patients operated on transsphenoidally 1985.

54 Kovacs K \& Horvath E. Effects of medical therapy on pituitary tumors. Ultrastructural Pathology 200529 163-167. 
55 Schottke H, Saeger W, Lüdecke DK \& Caselitz J. Ultrastructura morphometry of prolactin secreting adenomas treated with dopamine agonists. Pathology, Research and Practice 1986181 280-290.

56 Hallenga B, Saeger W \& Lüdecke DK. Necroses of Prolactinsecreting pituitary adenomas under treatment with dopamine agonists: light microscopical and morpho-metric studies. Experimental and Clinical Endocrinology 1988 92 59-68.

57 Horvath E \& Kovacs K. Ultrastructural diagnosis of human pituitary adenomas. Microscopy Research and Technique 199220 107-135.

58 Trouillas J \& Girod C. Pathology of pituitary adenomas. In Pituitary Adenomas, pp 27-46. Eds AM Landolt, ML Vance \& PL Reilly, Edinburgh: Churchill Livingstone, 1996.

59 Berg KK, Scheithauer BW, Felix I, Kovacs K, Horvath E, Klee GG \& Laws ER Jr. Pituitary adenomas that produce adrenocorticotropic hormone and a-subunit: clinicopathological, immunohistochemical, ultrastructural, and immunoelectron microscopic studies in nine cases. Neurosurgery 199026 397-403.

60 Föller TC, Saeger W \& Lüdecke DK. Immunohistological studies for gastrointestinal and other hormones in ACTH-secreting adenomas. Endocrine Pathology 19923 188-193.

61 Reuss W, Saeger W \& Lüdecke DK. Electron microscopical morphometry of well-differentiated and undifferentiated ACTH secreting adenomas in Cushing's disease and Nelson's syndrome. Virchows Archiv. A, Pathological Anatomy $1991419395-401$.

62 Scheithauer BW, Kovacs KT, Laws ER \& Randall RV. Pathology of invasive pituitary tumors with special reference to functional classification. Neurosurgery $198665733-744$.

63 Crooke AC. A change in the basophil cells of the pituitary gland common to conditions which exhibit the syndrome attributed to basophil adenoma. Journal of Pathology and Bacteriology 1935 41 339-349.

64 Saeger W, Lüdecke DK \& Geisler F. The anterior lobe in Cushing's disease/syndrome. In Cushing's Syndrome, and Other Hypercortisolemic Sstates. Progress on Endocrine Research and Surgery, Cushing's Syndrome, and Other Hypercortisolemic Sstates. Progress on Endocrine Research and Surgery, vol 5, pp 147-156. Eds DK Lüdecke, C Chrousos \& G Tolis, New York: Raven Press, 1990.

65 Saeger W. Zur Ultrastruktur der hyperplastischen und adenomatösen ACTH-Zellen beim Cushing-Syndrom hypothalamisch-hypophysärer Genese. Virchows Archiv. A, Pathological Anatomy 1974362 73-88.

66 Lüdecke DK, Flitsch J, Knappe UJ \& Saeger W. Cushing's disease: a surgical view. Journal of Neuro-Oncology 200154 151-166.

67 George DH, Scheithauer BW, Kovacs K, Horvath E, Young WF, Lloyd RV \& Meyer FB. Crooke's cell adenoma of the pituitary - an aggressive variant of corticotroph adenoma. American Journal of Surgical Pathology 200327 1330-1336.

68 Kurosaki M, Saeger W \& Lüdecke DK. Pituitary tumors in the elderly. Pathology, Research and Practice 2001197 493-497.

69 Scheithauer BW, Kovacs KT, Laws ER \& Randall RV. Pathology of invasive pituitary tumors with special reference to functional classification. Journal of Neurosurgery $1986 \mathbf{6 5} 733-744$.

70 Sanno N, Teramoto A \& Osamura RY. Long-term surgical outcome in 16 patients with thyrotropin pituitary adenoma. Journal of Neurosurgery 200093 194-200.

71 Saeger W \& Lüdecke DK. Pituitary adenomas with hyperfunction of TSH. Frequency, histological classification, immunocytochemistry and ultrastructure. Virchows Archiv. A, Pathological Anatomy $1982394255-267$.

72 Scheithauer BW, Kovacs K, Randall RV \& Ryan N. Pituitary gland in hypothyroidism. Histologic and immunocytologic study. Archives of Pathology and Laboratory Medicine 1985109 499-504.

73 Saeger W. Effect of drugs on pituitary ultrastructure. Microscopy Research and Technique 199220 162-176.

74 Horvath E \& Kovacs K. Gonadotroph adenomas of the human pituitary: sex-related fine-structural dichotomy. A histologic, immunocytochemical, and electron-microscopic study of 30 tumors. American Journal of Pathology 1984117 429-440.

75 Sano T, Mader R, Asa SL, Qian ZR, Hino A \& Yamada S. 'Honeycomb Golgi' in pituitary adenomas: not a marker of gonadotroph adenomas. Endocrine Pathology 200314 363-368.
76 Young WF, Scheithauer BW, Kovacs K, Horvath E, Davis DH \& Randall RV. Gonadotroph adenoma of the pituitary gland: a clinicopathologic analysis of 100 cases. Mayo Clinic Proceedings 199671 649-656.

77 Kontogeorgos G, Kovacs K, Horvath E \& Scheithauer BW. Null cell adenomas, oncocytomas, and gonadotroph adenomas of the human pituitary - an immunocytochemical and ultrastructural analysis of 300 cases. Endocrine Pathology 19934 20-27.

78 Lloyd RV, Scheithauer BW, Kovacs K \& Roche PC. The immunophenotype of pituitary adenomas. Endocrine Pathology 19967 145-150.

79 Niveiro M, Aranda FI, Paya A, Boix E, Peiro G \& Pico A. Oncocytic transformation in pituitary adenomas - immunohistochemical analyses of 65 cases. Archives of Pathology and Laboratory Medicine 2004128 776-780.

80 Diehl S, Weber T, Hamester U, Saeger W \& Lüdecke DK. Light microscopical morphometric classification of oncocytic and chromophobe pituitary adenomas. Experimental and Clinical Endocrinology 198891 341-349.

81 Landolt AM \& Heitz PU. Alpha-subunit-producing pituitary adenomas. Immunocytochemical and ultrastructural studies. Virchows Archiv. A, Pathological Anatomy 1986409 417-431.

82 Kovacs K, Horvath E, Bayley TA, Hassaram S \& Ezrin C. Silent corticotroph cell adenoma with lysosomal accumulation and crinophagy. A distinct clinicopathologic entity. American Journal of Medicine 197864 492-498.

83 Horvath E, Kovacs K, Smyth HS, Killinger DW, Scheithauer B, Randall R, Laws ER Jr \& Singer W. A novel type of pituitary adenoma: morphological features and clinical correlations. Journal of Clinical Endocrinology and Metabolism 198866 1111-1118.

84 DeLellis RA, Lloyd RV \& Heitz PU. Pathology and Genetics: Tumours of Endocrine Organs (World Health Organization Classification of Tumours) Lyon: International Agency for Research and Cancer (IARC), 2004.

85 Kurosaki M, Watanabe T, Saeger W \& Lüdecke DK. Intrasellar gangliocytomas associated with acromegaly. Brain Tumor Pathology $20021963-67$.

86 Saeger W, Lüdecke DK \& Losa M. Kombinierte neuronale und endokrine Tumoren der Sellaregion. Der Pathologe 1997 18419-424.

87 Saeger W, Puchner MJA \& Lüdecke DK. Combined sellar gangliocytoma and pituitary adenoma in acromegaly or Cushing's disease. A report of 3 cases. Virchows Archiv. A, Pathological Anatomy $1994 \mathbf{4 2 5}$ 93-99.

88 Scheithauer BW, Kovacs K, Randall RV, Horvath E, Okazaki H \& Laws ER Jr. Hypothalamic neuronal hamartoma and adenohypophyseal neuronal choristoma: their association with growth hormone adenoma of the pituitary gland. Journal of Neuropathology and Experimental Neurology $1983 \mathbf{4 2} 648-663$.

89 Horvath E, Kovacs K, Scheithauer BW, Lloyd RV \& Smyth HS. Pituitary adenoma with neuronal choristoma (PANCH): composite lesion or lineage infidelity? Ultrastructural Pathology $1994 \mathbf{1 8}$ 565-574.

90 Flitsch J, Lüdecke DK, Saeger W \& Westphal M. Dedifferentiation of a growth-hormone secreting pituitary adenoma to a non-secreting carcinoma. Experimental and Clinical Endocrinology and Diabetes 2005113 S67 (Abstr. Nr. 158).

91 Lübke D \& Saeger W. Carcinomas of the pituitary: definition and review of the literature. General and Diagnostic Pathology 1995141 81-92.

92 Gaffey TA, Scheithauer BW, Lloyd RV, Burger PC, Robbins P, Fereidooni F, Horvath E, Kovacs K, Kuroki T, Young WF, Sebo TJ, Riehle DL \& Belzberg AJ. Corticotroph carcinoma of the pituitary: a clinicopathological study. Journal of Neurosurgery 200296 352-360.

93 Cai WY, Alexander JM, Hedley-Whyte ET, Scheithauer BW, Jameson JL, Zervas NT \& Klibanski A. Ras mutations in human prolactinomas and pituitary carcinomas. Journal of Clinical Endocrinology and Metabolism 199478 89-93.

94 Nose-Alberti V, Mesquita MIS, Martin LC \& Kayath MJ. Adrenocorticotropin-producing pituitary carcinoma with expression of 
c-erbB-2 and high PCNA index: a comparative study with pituitary adenomas and normal pituitary tissues. Endocrine Pathology 1998 9 53-62.

95 Saeger W \& Lübke D. Pituitary carcinoma: a review. Endocrine Pathology $1996721-35$.

96 Landman RE, Horwith M, Peterson RE, Khandji AG \& Wardlaw SL. Long-term survival with ACTH-secreting carcinoma of the pituitary: a case report and review of the literature. Journal of Clinical Endocrinology and Metabolism 200287 3084-3089.
97 Saeger W. Hypophysentumoren. Der Pathologe 200324 255-264. 98 Saeger W. Raumfordernde Prozesse der Sellaregion unter besonderer Berücksichtigung Tumor-ähnlicher Läsionen. Der Pathologe 200324 247-254.

Received 25 July 2006

Accepted 2 November 2006 